\title{
Hereditary papillary renal cell carcinoma
}

INSERM

\section{Source}

INSERM. (1999). Orphanet: an online rare disease and orphan drug data base. Hereditary papillary renal cell carcinoma. ORPHA:47044

Hereditary papillary renal cell carcinoma (HPRCC) is a familial renal cancer syndrome characterised by a predisposition for developing bilateral and multifocal type 1 papillary renal carcinomas. 